\title{
Targeted Ablation of Diverse Cell Classes in the Nervous System in vivo
}

\author{
Sheila Nirenberg a and Constance Cepko \\ Department of Genetics, Harvard Medical School, Boston, Massachusetts 02115
}

The study of both the function and development of complex neural systems would be greatly facilitated by a means for systematically blocking intercell communication. One way of preventing cells from signaling each other is to remove them from the system by ablation. Here we present a general technique for visualizing and ablating selected cell classes in vivo. The cells of interest are genetically engineered so that they can be selectively labeled with a photoactivatable dye and visualized in living preparations; the dye-labeled cells can then be photoablated. This approach is applicable to a broad range of cell types, in organisms amenable to gene transfer, and permits ablations to be performed at different developmental stages or in the adult. We demonstrate the use of this technique on several cell types in the mouse retina and cerebral cortex, and in the zebrafish embyro.

[Key words: ablation, $\beta$-galactosidase, retina, cortex, signaling, lineage, commitment]

The development of a neural circuit is presumed to involve a complex pattern of cell-cell interactions. One approach to unraveling these interactions is to systematically ablate different classes of cells from the circuit as it is being formed. By removing a cell class, one can determine its role in development; moreover, by removing a cell class at different stages of development, one can examine separately the different functions it may play at different developmental stages (e.g., regulating proliferation, cell fate, neurite guidance). Similarly, the physiological function of a cell class in the mature neural circuit can be examined by lesioning the cells in the adult animal.

To serve as a useful tool for studying cell-cell interactions, an ablation technique should provide certain features: it should allow cells to be targeted as a class or individually, it must be effective on a wide range of cell classes, and it should provide

\footnotetext{
Received Dec. 11, 1992; accepted Mar. 1, 1993.

This work was supported by grants from the Lucille P. Markey Charitable Trust Program in the Cellular Basis of Development (S.N.) and NIH R01-EY08064 (C.L.C.). We thank Don Zack and Jeremy Nathans for the use of their rhodopsin$\beta$-gal transgenic mice, Richard Goodman and Malcolm Low for the use of their somatostatin and VIP- $\beta$-gal transgenic mice, and Carl Fulwiler for providing zebrafish embryos injected with $\beta$-gal constructs and for sharing his unpublished protocol for osmotic-shock labeling of zebrafish embryos with FDG. We also thank David Corey for help with image enhancement; Leonard Lerman, Sus Ito, Louise Trakimas, Elio Raviola, Steve Benton, Mike Klug, and Tayaba Hassan for use of their equipment and technical assistance; and Dave Turner, John Assad, Liz Ryder, Cliff Tabin, Bruce Morgan, Ed Laufer, Michael Shen, Steve Burden, and members of our laboratory for help with the manuscript.

Correspondence should be addressed to Dr. Constance Cepko, Department of Genetics, Harvard Medical School, 200 Longwood Avenue, Boston, MA 02115.

* Present address: Department of Cell and Developmental Biology, Harvard University, 16 Divinity Avenue, Cambridge, MA 02138.
}

Copyright (C) 1993 Society for Neuroscience $0270-6474 / 93 / 133238-14 \$ 05.00 / 0$ flexibility as to time of ablation. Current methods for ablating cells are limited in one or more of these respects. Laser and dyemediated photoablation techniques, used widely in invertebrates, involve manual targeting and thus are not practical for ablating large numbers of cells (Miller and Selverston, 1979; Sulston and White, 1980; Bentley and Caudy, 1983; Raper et al., 1984). Methods involving retrograde transport of toxins, such as toxic lectins (Wiley and Stirpe, 1988) and phototoxic dyes (Madison et al., 1990), allow larger scale ablations, but are inherently restricted to use in projection neurons. More recent approaches, involving selective expression of toxin genes (Breitman et al., 1987), are likely to be useful for studying cell-cell interactions in early organogenesis, but are not widely applicable to studies in nervous system development or function. For this approach, cells are ablated by generating transgenic animals that carry a toxin gene under the regulation of a cell type-specific promoter. In the nervous system, promoters specific to individual ccll types are rare, as most genes involved in the development or function of one area (e.g., genes for neuropeptides, neurotransmitter enzymes, growth factors) have been shown to be expressed in other areas as well (Schwartz and Costa, 1986; Marti et al., 1987; Zackary et al., 1987). Linkage of a toxin gene to most known promoters would therefore produce multiple lesions, which may confound interpretation of experiments or kill the animal. The promoter-toxin strategy also lacks temporal flexibility: the cell class is ablated at the onset of promoter activation, precluding the use of this method for studying the function of mature circuits.

The technique described in this article is a modification of the genetic approach that will permit a large number of different cell types to be targeted without requiring the identification of highly specific promoters. Rather than linking a promoter directly to a toxin gene, a promoter is linked to the Escherichia coli lac $Z$ gene, which encodes the nontoxic enzyme $\beta$-galactosidase ( $\beta$-gal). All cell types in which the promoter is active will express $\beta$-gal; since the enzyme is not lethal in itself, the cells remain intact. To ablate the cells of interest, a substrate for the enzyme, comprising a photoactivatable dye linked to a sugar moiety, is then applied to the tissue containing the cells. The substrate is taken up by most or all cells in the tissue, but cleaved to release detectable amounts of the dye only in those cells producing the exogenous $\beta$-gal enzyme. The dye-filled cells can then be photoablated, with the aid of a sensitizing agent.

The advantage to this approach is that the specificity of the ablation is not controlled solely by the promoter, but by the combination of the promoter and restricted illumination. This permits promoters active in multiple tissues to be utilized without losing ablation specificity. Because the number of different promoters that can be used to select cells is thus expanded, the 
number of different cell types that can be targeted is greatly increased. Furthermore, the time of ablation is flexible, as it is a function of the time of illumination.

We have tested this technique in vivo and in vitro on three different classes of cells in the mouse retina-two subclasses of amacrine cells and rod photoreceptors. Our goal is to be able to dissect the pattern of interactions involved in the formation of retinal circuits. To test the general utility of this technique, we have also targeted neurons in the mouse cerebral cortex in vivo, and cells in developing zebrafish embryos. In addition we demonstrate livelabeling of individual cell classes. The ability to identify specific classes of cells in situ is valuable for characterizing the cells physiologically and anatomically and for studying the dynamic behavior of the cells in the context of developing tissue.

\section{Materials and Methods}

\section{Live labeling of $\beta$-gal-expressing cells using \\ fluorescein-di- $\beta$-D-galactopyranoside (FDG)}

All cell types targeted for ablation in the mouse were first engincered to express $E$. coli lac $Z$ by generating transgenic lines that express lac $Z$ under the regulation of cell type-specific promoters. Three different transgenic mouse lines were used, each utilizing a different promoter. The promoters for the vasoactive intestinal peptide (VIP) and somatostatin genes were used to target two different classes of amacrine cells, and the promoter to the rhodopsin gene was used to target rod photoreceptors. The VIP- $\beta$-gal and somatostatin- $\beta$-gal transgenic mouse lines were obtained from Malcolm Low and Richard Goodman; the rhodopsin- $\beta$-gal line was obtained from Don Zack and Jeremy Nathans. Adult animals and animals older than postnatal day 7 were anesthetized by intraperitoneal injection of $0.03 \mathrm{cc}$ ketamine/xylazine $(100 \mathrm{mg} / \mathrm{ml}$ ketamine $\mathrm{HCl}, 20 \mathrm{mg} / \mathrm{ml}$ xylazine). Younger animals were anesthetized using either cryoanesthesia or ether.

$\beta$-gal ${ }^{+}$cclls in the retina were labeled in vivo by injecting a solution of FDG [0.5 $\mu$ l of $10-20 \mathrm{~mm}$ in $25 \%$ dimethyl sulfoxide (DMSO) $/ 75 \%$ PBS] into the eye. The injection was made by puncturing the cornea with a 30 gauge needle and inserting the tip of a Hamilton syringe (33 gauge, blunt tip, $10 \mu \mathrm{l}$ ) into the opening. The fluorescein-labeled cells were then visualized by placing the mouse on the microscope stage so that the microscope objective could be focused through the animal's lens onto the retina (Fig. $1 \mathrm{~A}$ ). Corneal refraction was reduced by placing a glass coverslip over the animal's eye. Tissue was illuminated using a standard fluorescence microscope (Zeiss Axiophot equipped with 100 W mercury short arc bulb, standard fluorescein filter set: exciter filter, $450-490 \mathrm{~nm}$; dichroic filter, $510 \mathrm{~nm}$; barrier filter, $520-560 \mathrm{~nm}$ ).

$\beta$-gal ${ }^{+}$cells in the retina were labeled in vitro by placing the retina, ganglion cell surface up, in a minimal volume of $L-15$ medium or saline (just enough to cover tissue) and dropping 2-3 $\mu$ l of FDG solution (8 $\mathrm{mM}$ in $10 \%$ DMSO) onto the surface of the tissue (Fig. 1B). The solution was then immediately diluted 10 -fold in the L- 15 medium. This procedure yielded a more effective and homogeneous labeling than immersing the tissue in diluted FDG solution.

$\beta$-gal ${ }^{+}$cells in the cerebral cortex were labeled in vivo by opening the skin above the skull, reflecting the skull or removing the bone, and applying FDG solution ( $8 \mathrm{~mm}$ in $10 \% \mathrm{DMSO}$ ) to the surface of the brain (Fig. $1 C$ ). Tiny perforations were made in the dura with a 30 gauge needle to permit FDG entry into the tissue. In some experiments the dura was removed and the FDG solution was applied directly to the pial surface.

It has been reported that labeling both mouse fibroblast and Drosophila embryo cells with FDG for fluorescence-activated cell sorting (FACS) requires osmotic shock (Nolan et al., 1988; Krasnow et al., 1991). We found that osmotic shock was not necessary in the tissues we tested: neurons in retina and cortex, both in vivo and in tissue slices, showed robust labeling without osmotic shock. FDG was not highly effective in labeling dissociated $\beta$-gal ${ }^{+}$cells: in general, only a small fraction of $\beta$-gal ${ }^{+}$cells (using dissociated retinal cells and fibroblast cell lines) showed bright fluorescein labeling, with or without osmotic shock (S. Nirenberg, unpublished observations). Two new FDG analogs, $\mathrm{C}_{12}$ FDG and $\mathrm{C}_{8}$ FDG, apparently show better labeling for dissociated cells (Zhang et al., 1991).

\section{Photoablation procedure}

The eyes of anesthetized mice were injected with FDG mixed with 3-amino-9-ethylcarbazole (AEC) $(0.5 \mu \mathrm{ll} 100-200 \mathrm{~mm} \mathrm{FDG}, 10 \mathrm{mg} / \mathrm{ml}$ AEC in $70 \% \mathrm{DMSO} / 30 \% \mathrm{PBS}$ ), and the retina was illuminated in situ for 10 min using a $10 \times, 0.3 \mathrm{NA}$ objective (Zeiss). The volume of the adult mouse eye was estimated to be 5-10 $\mu \mathrm{l}$; thus, each compound was diluted 10-20-fold. A glass coverslip was placed over the eye to reduce corneal refraction. The microscope was focused on the labeled cells in the retina. Once focused, the $10 \times$ objective illuminated a $3 \mathrm{~mm}$ spot at the surface of the cornea. The incident light was further focused by the optics of the eye to a $1.5-2.3 \mathrm{~mm}$ spot at the plane of the labeled cells, determined by measuring the size of the area containing cells with photoreacted AEC (see Results).

For ablations in vitro, the retina was first placed in a volume of PBS just sufficient to cover the tissue and 2-3 $\mu \mathrm{l}$ of FDG/AEC (10-20 mM FDG, $4 \mathrm{mg} / \mathrm{ml} \mathrm{AEC} \mathrm{in} 70 \%$ DMSO) was dropped onto the the ganglion cell surface. The FDG/AEC solution was then immediately diluted 50fold in L-15 medium or PBS. Within $1 \mathrm{~min}$ of FDG/AEC application, the $\beta$-gal ${ }^{+}$cells in the tissue were labeled with fluorescein. The tissue was then washed three times in PBS and illuminated for 10 min using either a $10 \times, 0.3 \mathrm{NA}$ or $20 \times, 0.5 \mathrm{NA}$ objective (Zeiss).

The procedure for ablating cortical $\beta$-gal ${ }^{+}$cells was similar: FDG/ AEC solution ( $40-80 \mathrm{mM}$ FDG $4 \mathrm{mg} / \mathrm{ml}$ AEC, $70 \% \mathrm{DMSO}$ ) was placed on the pia (or dura; see above) for $30 \mathrm{sec}$ and then diluted 50 -fold by applying saline to the cortical surface. The surface of the brain was washed twice and kept moist with saline. The cortex was then illuminated for $10 \mathrm{~min}$ using either a $10 \times, 0.3 \mathrm{NA}$ or $20 \times, 0.5 \mathrm{NA}$ objective (Zeiss).

It should be noted that high concentrations of DMSO were used to dissolve FDG and AEC. While no DMSO-induced cell death was detected in any of the tissues examined here (mouse retina, cortex, whole zebrafish embryo), DMSO in high concentrations has been reported to be teratogenic in some systems (Brennan, 1991).

\section{Assays for cell death}

The effectiveness of the ablation treatment was assayed two ways: First, the targeted population of cells was scored immediately after treatment for the uptake of dyes that are excluded from live cells, ethidium homodimer and trypan blue (Steinkamp et al., 1987; Lees, 1989; Beletsky and Umansky, 1990; Macklis and Madison, 1990; Ruiz et al., 1991). Second, 1-2 weeks after treatment, treated tissue was examined for the loss of the $\beta$-gal ${ }^{+}$cells, using the $\beta$-gal substrate 5 -bromo-4-chloro-3indolyl $\beta$-D-galactoside (Xgal).

Ethidium and trypan blue assays. After ablation treatment, retinas were immersed in a solution of ethidium homodimer $(30 \mu \mathrm{g} / \mathrm{ml}$ in PBS). The targeted $\beta$-gal ${ }^{+}$cells in each retina were then scored for uptake of ethidium. In all experiments, retinas were placed in ethidium immediately after ablation treatment and maintained at $37^{\circ} \mathrm{C}$ to allow the dye to penetrate the tissue. The red ethidium fluorescence was viewed using a $630-640 \mathrm{~nm}$ bandpass filter. The standard rhodamine barrier filter, $590 \mathrm{~nm}$ longpass, could not be used, since, in some experiments, the fluorescein fluorescence of some of the brighter cells was faintly detectable through the rhodamine filter; this was completely blocked using the longer-wavelength $(630-640 \mathrm{~nm})$ filter set. Each retina was photographed at $200 \times$ magnification to show $\beta$-gal ${ }^{+}$cells and, separately, to show ethidium ${ }^{+}$cells. The position of each $\beta$-gal ${ }^{+}$cell was then traced from the photograph onto a transparency and superimposed on the photograph showing the ethidium ${ }^{+}$cells in the identical region of tissue. To quantify ablation effectiveness, the proportion of $\beta$-gal ${ }^{+}$ cells (scored by the presence of AEC or fluorescein) that were also ethidium ${ }^{+}$was determined in a $400 \mu \mathrm{m} \times 400 \mu \mathrm{m}$ sampling grid within the ganglion cell/amacrine cell layer of each retina. For several retinas, trypan blue $(0.4 \%)$ (Lees, 1989) was used as a second marker for cell death.

To quantify the amount of nonspecific cell death that may have occurred, the percentage of $\beta$-gal ${ }^{-} /$ethidium $^{+}$cells was determined in each sampling grid by dividing the $\beta$-gal ${ }^{-} /$ethidium $^{+}$cells by the total number of all cells that would be contained within the sampling grid. The grid had lateral dimensions of $400 \mu \mathrm{m} \times 400 \mu \mathrm{m}$, and was confined to a single plane of focus in depth. To ensure a conservative (i.e., upper limit) estimate of nonspecific cell death, we estimated the total number of cells in the grid by assuming the plane of focus to be extremely narrow: a line was drawn through the ganglion cell layer in a cresyl violet-stained transverse section, and the total number of cell bodies that intersected 

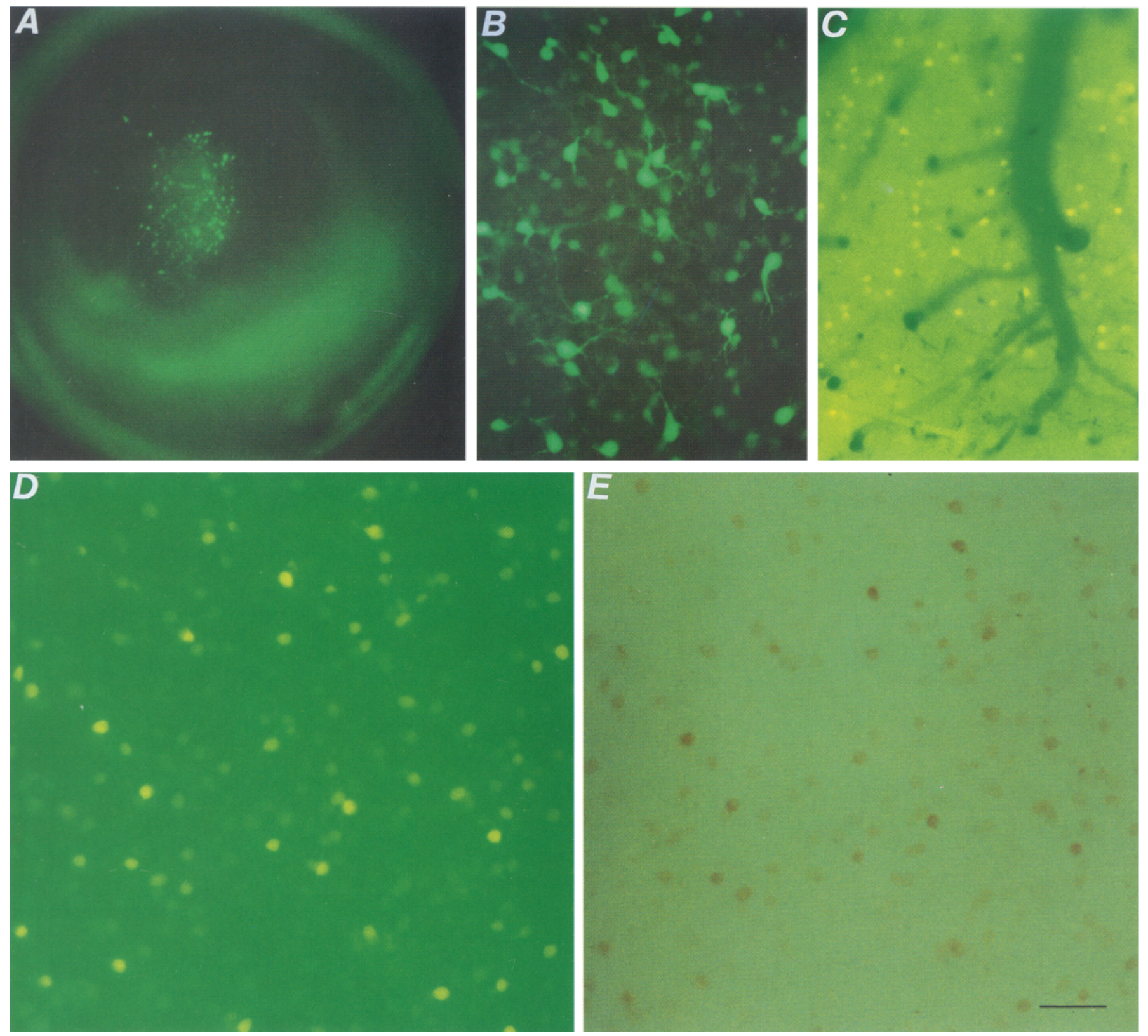

Figure 1. Live labeling of discrete neuronal populations in vivo and in vitro using FDG, a fluorogenic substrate for the $\beta$-gal enzyme. $A$, Intact eye of a live, VIP- $\beta$-gal transgenic mouse, injected with FDG. Cleavage of FDG by the $\beta$-gal enzyme released fluorescein into the VIP- $\beta$-gal neurons in the retina. The cells were viewed by placing the mouse on the stage of an upright fluorescence microscope and illuminating the retina through the intact eye, using a $2.5 \times$ objective. $B$, Retina from a newborn somatostatin- $\beta$-gal transgenic mouse, labeled with FDG in vitro. $C$, Cerebral cortex of VIP- $\beta$-gal transgenic mouse, labeled with FDG in vivo. The VIP- $\beta$-gal cells in the cortex were labeled by removing a portion of the skull and applying FDG directly to the dura, which had been perforated with a 30 gauge needle to permit the $\beta$-gal substrate to diffuse into the brain. $D$ and $E$, Retina from a VIP- $\beta$-gal transgenic mouse immersed in FDG solution with AEC. Cleavage of FDG by the $\beta$-gal enzyme released fluorescein into the VIP- $\beta$-gal cells $(D)$. Illumination of tissue caused the colorless AEC to form a visible brown precipitate in the fluorescein-labeled cells $(E)$. Scale bar: $200 \mu \mathrm{m}$ for $A ; 25 \mu \mathrm{m}$ for $B, D$, and $E ; 50 \mu \mathrm{m}$ for $C$.

the line was determined. This quantity was then scaled by the lateral dimensions of the grid to estimate the total number of cells per grid. The actual depth of field for fluorescence imaging of ethidium-labeled cells extended over tens of microns; by assuming essentially zero depth of field, this procedure underestimated the total number of cells, and thus overestimated the percentage of cells killed nonspecifically. Thus, the estimated percentage of cells killed nonspecifically represents an upper limit.

Xgal assay. To examine whether the targeted neurons were absent after a longer period of time following in vivo ablation, $\beta$-gal activity was assayed using Xgal, a $\beta$-gal substrate that forms a blue precipitate. One to two weeks after ablation treatment, retinas were removed and fixed in $0.5 \%$ glutaraldehyde or $4 \%$ paraformaldehyde in PBS for 15 $\mathrm{min}$, and then processed for Xgal following the procedure of Cepko (1989). For cortical ablations, brains were fixed in 4\% paraformaldehyde for $2 \mathrm{hr}$. Xgal-labeled whole-mounts (retinas) or coronal sections (cortex) were then traced at $400 \times$ by camera lucida, and the position of $\mathrm{Xgal}^{+}$ cells marked. The ablation procedure created large, sharply delineated "blank patches" devoid of $\mathrm{Xgal}^{+}$cells in the treated tissues. For the retinas, the size of the blank patches was quantified by placing a grid array of $100 \mu \mathrm{m} \times 100 \mu \mathrm{m}$ sampling squares over the camera lucida reconstruction and counting the number of $\mathrm{Xgal}^{+}$cells in each sampling square. An individual square was scored as "blank" if it contained two or fewer $\mathrm{Xgal}^{+}$cells. The total size of the blank patch was taken to be 
the largest contiguous set of blank sampling squares, in which each square bordered at least one other blank square. The $100 \mu \mathrm{m} \times 100$ $\mu \mathrm{m}$ size and the two-cell criterion were chosen based on measurements in untreated retinas stained with Xgal: in four untreated retinas $(n=6$ squares sampled in each), the average number of $\mathrm{Xgal}^{+}$cells per randomly chosen $100 \mu \mathrm{m} \times 100 \mu \mathrm{m}$ square was $5.3(\mathrm{SD}=1.1)$ in the lowest-density region of the retina, peripheral retina $(>1 \mathrm{~mm}$ from the optic nerve head), and $7.4(\mathrm{SD}=1.3)$ in central retina. Assuming a Gaussian distribution for the number of $\mathrm{Xgal}^{+}$cells per sampling square, the probability of a square containing two or fewer cells by chance is less than 0.0015 . This method provided a conservative estimate of the sizes of the blank patches, since sampling squares at the border of the blank patch were excluded by this criterion. Notwithstanding, the quantitative measurement agreed well with estimates of the size of the blank patches made by tracing the edge of the patch by eye. In the rhodopsin$\beta$-gal transgenic retinas, the blank patches were so clearly delineated that their size was measured solely by tracing the perimeter of the blank patch by eye. The same analysis was performed on control retinas (from VIP- $\beta$-gal and rhodopsin- $\beta$-gal transgenic animals) that were either treated with FDG and AEC but not illuminated, illuminated but not treated with FDG or AEC, or treated with FDG and illuminated without adding AEC.

For a fraction of VIP- $\beta$-gal retinas, the ablated region was interrupted with a streak of surviving $\beta$-gal ${ }^{+}$cells, often surrounding a blood vessel. In these retinas (see Fig. $3 E$ ), the size of the blank patch was counted as the sum of the areas on each side of the blood vessel, excluding the $\beta$-gal' region. We have observed that blood absorbs the incident wavelength and may have effectively protected surrounding tissue.

\section{Immunocytochemistry and cell counts}

To assess further the selectivity of the method, retinas from which the VIP- $\beta$-gal cells had been ablated were examined for the loss of two neighboring cell types, the large-bodied ganglion cells and the tyrosine hydroxylase-positive $\left(\mathrm{TH}^{+}\right)$amacrine cells, using cell type-specific antibodies. One to two weeks after ablation treatment had been applied in vivo, retinas were removed, fixed in $4 \%$ paraformaldehyde, stained with Xgal overnight, and washed three times in PBS. SMI32, a monoclonal antibody against a phosphorylation-independent epitope on the high-molecular-weight neurofilament (Sternberger and Sternberger, 1983), was used to label the large-bodied ganglion cells (Nixon et al., 1989). Rabbit antibodies to TH (Pel-Freeze, 1:250) were used to label $\mathrm{TH}^{+}$amacrine cells (Wulle and Schnitzer, 1989). To facilitate antibody penetration into tissue, retinas were first immersed in $30 \%$ sucrose/PBS, and then transferred onto glass coverslips and frozen and thawed twice on dry ice, as described by Tauchi et al. (1990). Retinas were then incubated in primary antibody (1:100 dilution for both SMI32 and TH) for $48 \mathrm{hr}$ at $4^{\circ} \mathrm{C}$ in Dulbecco's Modified Eagle's Medium (DMEM) containing $10 \%$ calf serum and $0.1 \%$ Triton $X-100$, followed by several washes in PBS $/ 0.1 \%$ Triton. Biotinylated secondary antibodies (Vector Labs; 1:500) were applied for $48 \mathrm{hr}$, followed by overnight washing. Retinas were then incubated overnight with streptavidin-conjugated alkaline phosphatase (Zymed; $1: 200$ ) in $0.1 \%$ BSA, $5 \mathrm{~mm}$ EDTA, and $0.5 \%$ Triton X-100 in PBS, followed by several washes over a period of $4 \mathrm{hr}$ with PBS/Triton X-100, followed by $2 \mathrm{hr}$ of washes with $10 \mathrm{~mm}$ $\mathrm{KH}_{2} \mathrm{PO}_{4}, \mathrm{pH} 6.5,0.5 \mathrm{M} \mathrm{NaCl}, 1 \mathrm{~mm}$ EDTA, $0.5 \%$ Triton X-100, and $0.1 \%$ BSA. Retinas were then washed twice for $5 \mathrm{~min}$ in $0.1 \mathrm{M}$ Tris$\mathrm{HCl}, \mathrm{pH} 8.8,0.1 \mathrm{M} \mathrm{NaCl}$, and $5 \mathrm{~mm} \mathrm{MgCl}_{2}$. Alkaline phosphatase reactions were performed by incubating retinas in $0.1 \mathrm{mg} / \mathrm{ml} 5$-bromo4-chloro-3-indoyl-phosphate, $1 \mathrm{mg} / \mathrm{ml}$ nitroblue tetrazolium (NBT) in $0.1 \mathrm{~m}$ Tris- $\mathrm{HCl}, \mathrm{pH} 8.8,0.1 \mathrm{M} \mathrm{NaCl}$, and $5 \mathrm{~mm} \mathrm{MgCl}$, for $10-20 \mathrm{~min}$.

Outlines of the retinas and the positions of the ganglion cells, $\mathrm{TH}^{+}$ amacrine cells, and $\mathrm{Xgal}^{+}$cells were traced by camera lucida at $400 \times$ magnification using a Computer-Aided Reconstruction Program (CARP) (Biographics, Dallas, TX) on a Sun 386i computer. Retinas were stained with either Xgal and SMI32, or Xgal and TH. In each retina, the number of cells of each type was measured in two identically sized sampling grids, one placed in the ablated area and the other placed in an adjacent nonablated area. Grids $400 \mu \mathrm{m} \times 400 \mu \mathrm{m}$ were used in SMI32-stained retinas; grids $400 \mu \mathrm{m} \times 800 \mu \mathrm{m}$ were used in the TH-stained retinas. The size and position of the sampling grids were chosen to minimize error that may result from the well-described changes in cell density that occur as a function of distance from central retina (Drager and Olson, 1981; Wulle and Schnitzer, 1989). For analysis of ganglion cell distribution, grids were placed in the peripheral region of the nasotemporal quadrant, where density changes are shallow and regular with distance from the optic nerve head (Drager and Olsen, 1981). In each retina, test and control grids were placed equidistant from the optic nerve head. $\mathrm{TH}^{+}$amacrine cells are evenly distributed across the retina (Wulle and Schnitzer, 1989), eliminating the possibility of error due to inhomogeneity of cell density.

\section{Photoablation of cells in zebrafish embryos}

Lebrafish eggs were injected with DNA constructs following a procedure of C. Fulwiler, P. Yelick, J. Dowling, and W. Gilbert (unpublished observations). The constructs contained either the murine heat-shock promoter (hsp) or an immediate-early cytomegalovirus promoter regulating $\beta$-gal. At various stages of development (earliest tested was 5 -somite stage), $\beta$-gal + cells were labeled with fluorescein using FDG. Embryos were dechorionated and osmotically shocked with FDG (8 $\mathrm{mM}$ in $10 \% \mathrm{DMSO} / 90 \%$ saline) according to a procedure developed by Carl Fulwiler for labeling zebrafish (Fulwiler ct al., unpublished observations). After treatment with FDG, the embryos were immersed in AEC solution ( $100 \mu \mathrm{g} / \mathrm{ml} \mathrm{AEC} \mathrm{in} 5 \%$ DMSO). The embryos were placed on a depression slide in $0.5 \mathrm{ml}$ vol and covered with a glass coverslip to reduce evaporation. The embryos were illuminated for $10 \mathrm{~min}$, using a $20 \times, 0.5$ NA objective. Ablation was assayed by immersing the embryos in propidium iodide $(1 \mathrm{mg} / \mathrm{ml})$.

\section{Results}

Labeling of the targeted cell type with a photoactivatable dye

The cell types selected for ablation were first engineered to express $E$. coli lac $Z$, which encodes $\beta$-gal, by generating transgenic mouse lines that express $l a c Z$ under the regulation of cell typespecific promoters. For ablation of retinal cells, three different transgenic mouse lines were used, each with a different promoter regulating $l a c Z$. The VIP and somatostatin gene promoters were used to target amacrine cells and the rhodopsin gene promoter was used to target rod photoreceptors. The cells expressing the $\beta$-gal enzyme were then selectively labeled by applying FDG, a $\beta$-gal substrate comprised of the dye fluorescein linked to a galactose backbone (Nolan et al., 1988). Figure 1 shows $\beta$-galexpressing $\left(\beta\right.$-gal $\left.{ }^{+}\right)$neurons, in the retina (A) and cerebral cortex (C) of a live mouse that have been labeled with fluorescein using FDG; the cells were expressing $\beta$-gal under the regulation of the VIP promoter.

\section{Mechanism of photoablation}

Light activation of fluorescein can be toxic to cells, including neurons (Cohan et al., 1983; Wayne, 1988) and fibroblasts (Nirenberg, unpublished observations). The toxicity likely results from the generation of reactive oxygen species, such as singlet oxygen (Wayne, 1988; Devanathan et al., 1990). Because fluorescein is primarily a fluorescing dye, the quantum yield of singlet oxygen is low (3\%); thus, high concentrations of excited fluorescein are necessary for lethal effects (Devanathan et al., 1990). We found that excitation of FDG-derived fluorescein was not lethal to retinal amacrine cells expressing $\beta$-gal under either the VIP or somatostatin promoter. Presumably, the accumulation of fluorescein was insufficient in these cell types. Halogenated fluoresceins, which have a higher quantum yield of singlet oxygen than fluorescein, were also not effective when linked to galactose (data not shown) and $\beta$-gal substrates made with these dyes tend to be less stable and/or poorer substrates for the enzyme than FDG (J. Naleway, personal communication). Since the fluorescein substrate was the most reliable, fluorescein was used as the photosensitizer, but its effects were amplified by the use of a second compound, AEC. AEC, a mild reducing agent, served as an amplifier by reacting with the products of excited fluorescein (presumably singlet oxygen) to form a lethal reaction product.

For each experiment, a solution of FDG and AEC was applied to the tissue containing the $\beta$-gal ${ }^{+}$cells. Once the cells were 

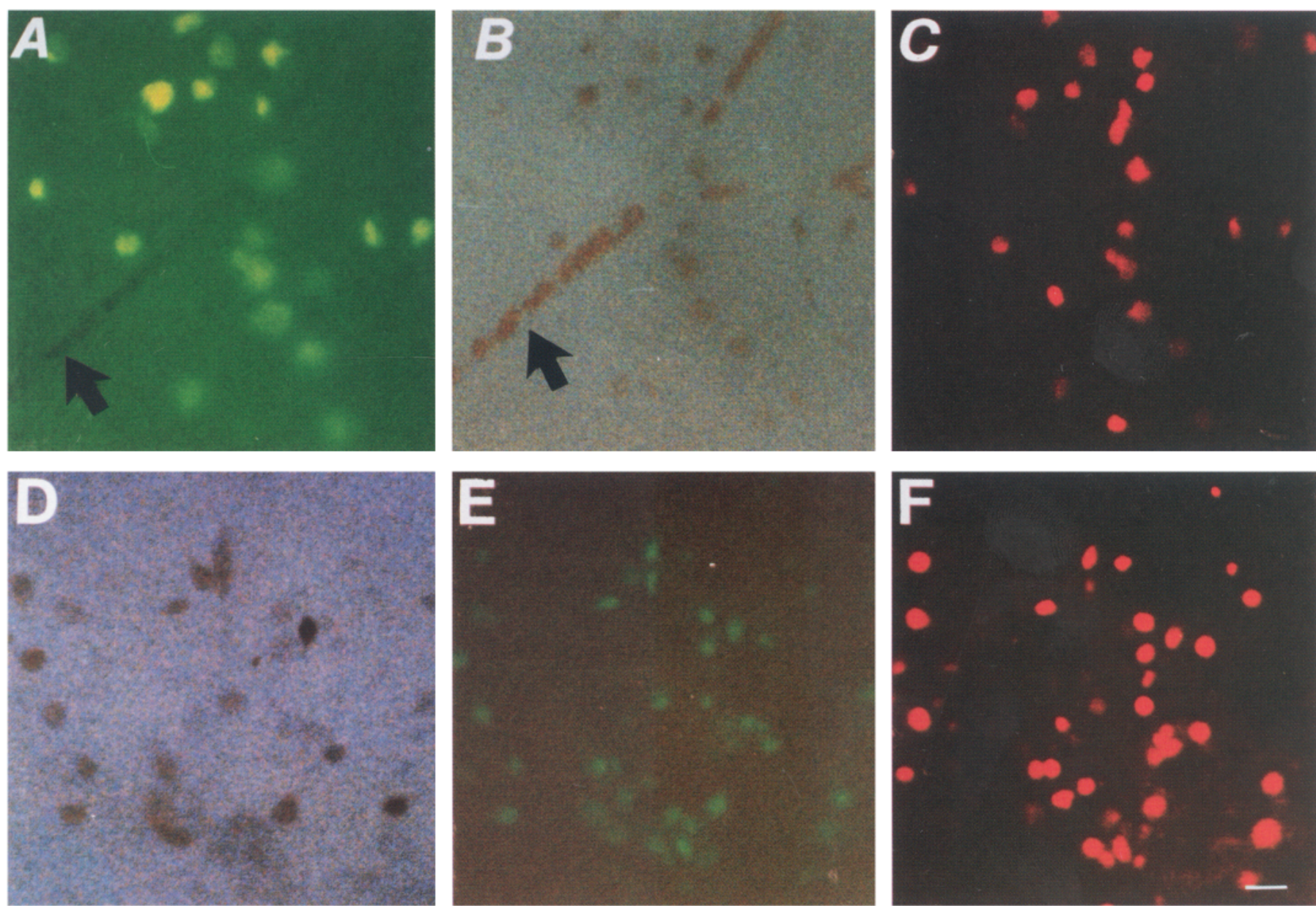

Figure 2. Selective uptake of ethidium into $\beta$-gal ${ }^{+}$cells in treated retinas. $A-C$, Retina from a VIP- $\beta$-gal transgenic mouse immersed in FDG/ AEC solution in vitro $(A)$. Vitreal surface is facing up. The VIP- $\beta$-gal cells were selectively labelej with fluorescein. After 5 min of illumination, the fluorescein-labeled cells $(A)$ showed the presence of AEC oxidation product $(B)$. (The diagonal band, arrow, is a blood vessel.) $C$, Same retina treated with ethidium homodimer. Approximately $4 \mathrm{hr}$ after treatment, AEC cells were selectively labeled with ethidium. $D-F$, Retina from a VIP$\beta$-gal transgenic mouse, removed from the animal after ablation treatment had been applied in vivo. $D$, Cells containing AEC precipitate. $E$, Residual unbleached fluorescein can be seen in $\beta$-gal ${ }^{+}$cells. Note that not all of the fluorescein-labeled cells $(E)$ showed dense AEC labeling in $D$. $F$, Same retina treated with ethidium homodimer. While not all of the fluorescein-labeled cells $(E)$ showed dense AEC precipitate, nearly all fluoresceinlabeled cells were ethidium labeled $(F) 30$ min after ablation treatment had been applied in vivo.

selectively labeled with fluorescein, light activation of the fluorescein in the presence of AEC caused a visible brown precipitate to form in those cells (Fig. 1D,E). Formation of the AEC precipitate, as shown below, was found to be cytotoxic.

It was not known a priori that AEC would increase toxicity. It was hypothesized that a nontoxic reducing agent with a lethal oxidation product could serve as an amplifier if it were readily oxidized in the presence of low levels of excited fluorescein. AEC was one of several compounds tested for this purpose. The others were Xgal and peroxidase substrates, the latter chosen as a result of the finding that diaminobenzidine will polymerize in the presence of excited Lucifer yellow (Maranto, 1982). In these experiments, only AEC was found to be toxic in conjunction with FDG.

\section{Assays for cell death}

The effectiveness of the ablation method was examined using two assays. First, the targeted $\beta$-gal ${ }^{+}$cells were scored immediately after treatment for selective uptake of two dyes, ethidium homodimer and trypan blue, which are excluded from live cells
(Steinkamp et al., 1987; Lees, 1989; Beletsky and Umansky, 1990; Macklis and Madison, 1990; Ruiz et al., 1991). Second, tissues that had contained $\beta$-gal ${ }^{+}$cells were examined 1 week or more after treatment for the selective loss of those cells.

The ethidium assay was applied to eight retinas, four containing VIP- $\beta$-gal ${ }^{+}$cells and four containing somatostatin $-\beta$ $\mathrm{gal}^{+}$cells. Since the fluorescein was often completely bleached by the ablation treatment, the colored AEC precipitate was used as a marker for the targeted population. Cell death was assayed by determining the proportion of AEC-marked cells that were labeled with ethidium (Fig. 2). In each retina, AEC-marked cells were scored in a $400 \mu \mathrm{m} \times 400 \mu \mathrm{m}$ region: In eight retinas, 93 $\pm 8 \%$ of AEC-labeled cells were also labeled with ethidium (total number of AEC-labeled cells $=404$ ). In four retinas in which fluorescein labeling was particularly strong, it was possible to detect residual, unbleached fluorescein after the retinas were removed from the animals (Fig. $2 D-F$ ). This permitted a direct assessment of the proportion of fluorescein-labeled cells that had taken up ethidium. Of the 357 total fluorescein-labeled cells, $94 \pm 5 \%$ showed the presence of ethidium. Thus, nearly all 


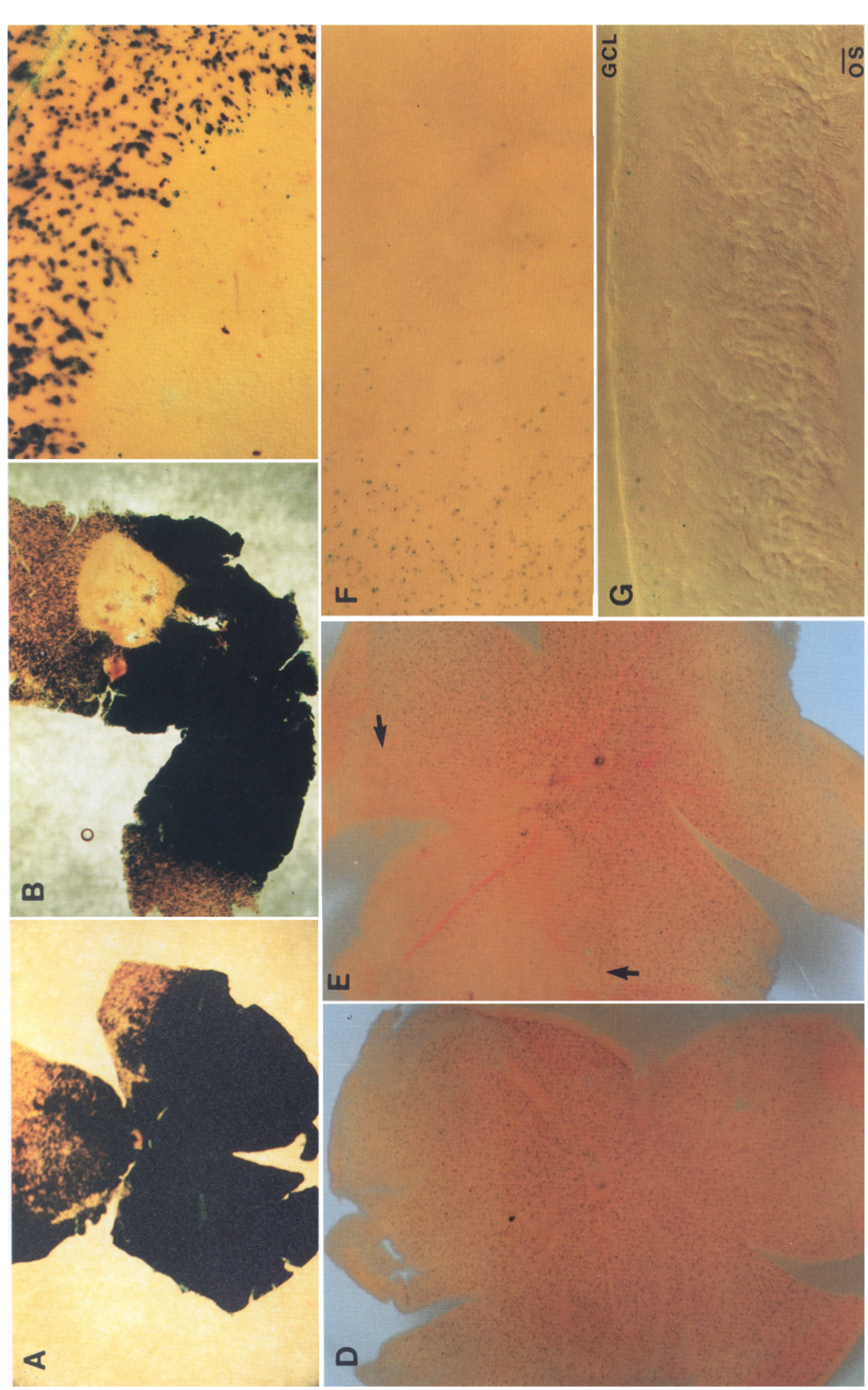

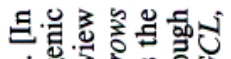

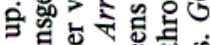

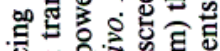

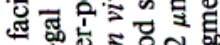
9 op. : 8.

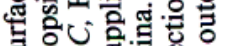
के

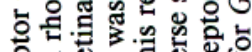
证

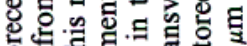

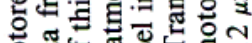

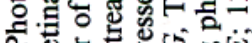
स.

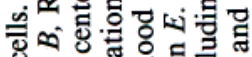

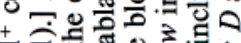
可的

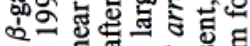

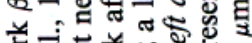

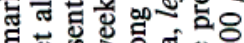

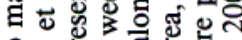

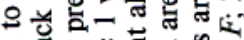

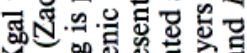
$x$ 吗青品

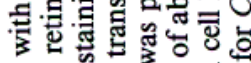

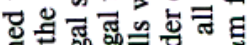

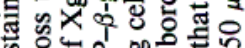
की 进 $>5$

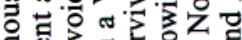

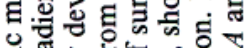

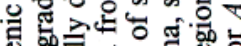
哑

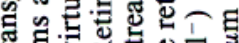
팅 車过

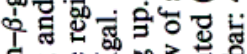

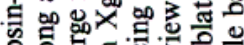

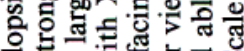

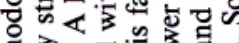
古定它它 ह 은.

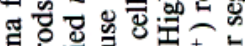

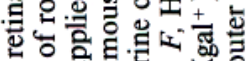
몽

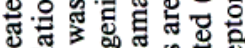

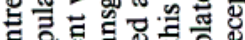
5 过

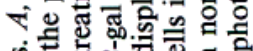
(1) 争. 记

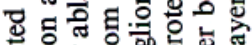

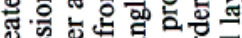
为造 a

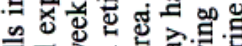

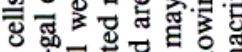
+ 二

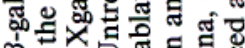

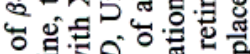
要

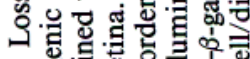
硛 r. 今 品

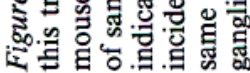



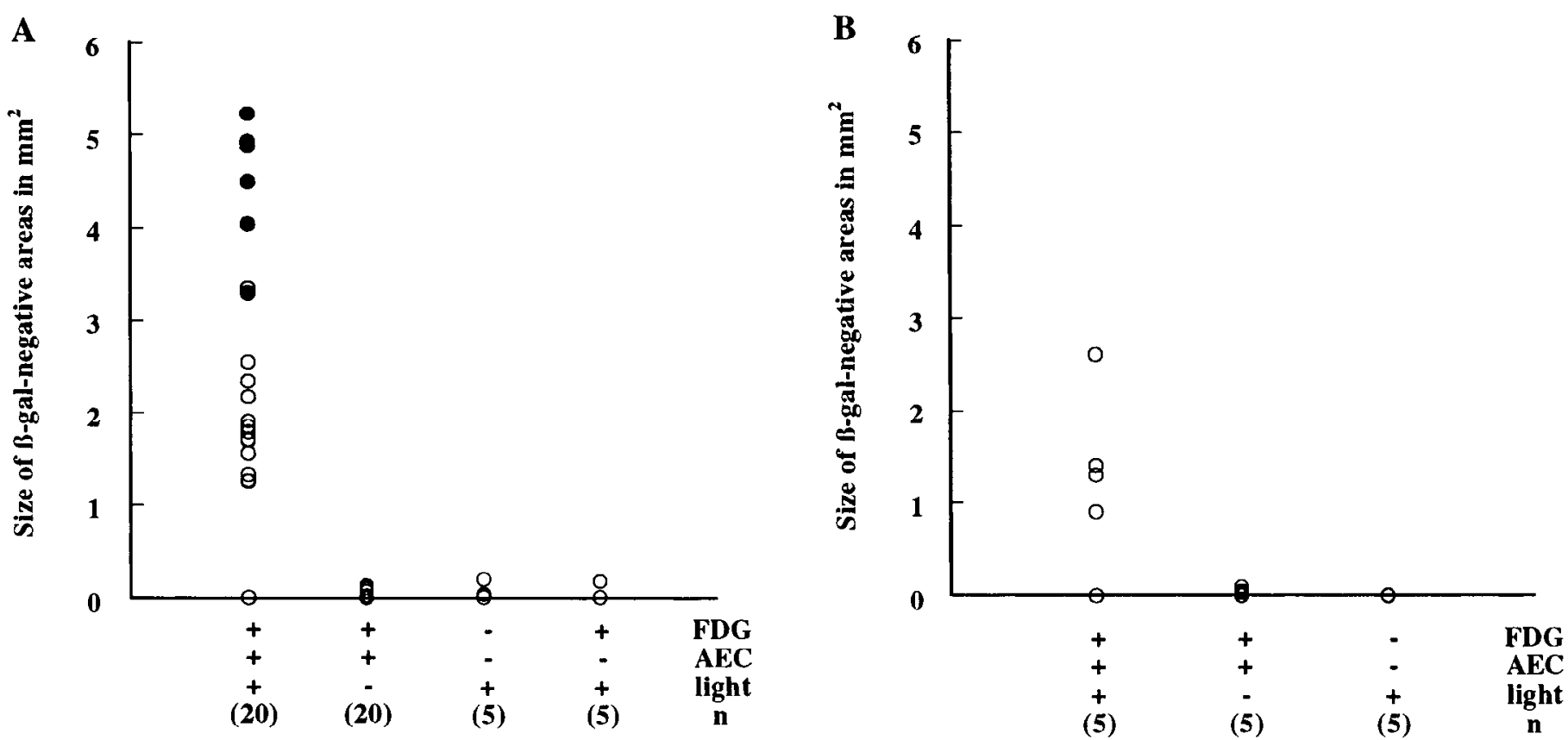

Figure 4. Size of the $\beta$-gal ${ }^{-}$regions in treated retinas and controls. Ablation treatment was applied in vivo to retinas in adult mice. Control retinas were either treated with FDG/AEC solution but not illuminated, or illuminated but not FDG/AEC treated, or treated with FDG and illuminated without the aid of the amplifier, AEC. One to two weeks later, retinas were removed and stained with Xgal to assay presence of $\beta$-gal ${ }^{+}$cells. For each retina, $\mathrm{Xgal}^{+}$cells were plotted on camera lucida drawings, and the sizes of the $\mathrm{Xgal}^{-}$regions measured. The size of each $\mathrm{Xgal}-{ }^{-}$area was determined by placing an array of $100 \mu \mathrm{m}$ by $100 \mu \mathrm{m}$ sampling grids over each camera lucida drawing and counting the number of contiguous grids that contained two or fewer $\mathrm{Xgal}^{+}$cells. Most grids contained zero cells. The mean density of $\mathrm{Xgal}^{+}$cells in the ablated areas for all retinas examined was $<3 \%$ of the mean density of $\mathrm{Xgal}^{+}$cells in control retinas (see Materials and Methods). The numbers in parentheses refer to the number of retinas in each group. $A$, Retinas from a VIP- $\beta$-gal transgenic mouse line. For some retinas, a larger area was irradiated by moving the animal after one spot was illuminated to permit the illumination of an adjacent spot. Open circles denote a single spot of illumination (approximately $1.5-2.3 \mathrm{~mm}$ diameter), solid circles denote two adjacent spots. $B$, Retinas from a rhodopsin- $\beta$-gal transgenic mouse line.

targeted cells in the illuminated regions were killed. It was observed in these four retinas that while $94 \%$ of fluorescein-labeled cells took up ethidium, not all of these cells contained visible AEC precipitate (Fig. 2D,E). Thus, although AEC was absolutely required for the ablation of these cells, the formation of visible AEC oxidation product did not appear to be required. Nonspecific damage was very low: fewer than $2 \%$ of nontargeted cells per field (cells not labeled with fluorescein and/or AEC) were labeled with ethidium, with a field containing 1500-2000 cells in the ganglion cell/displaced amacrine cell layer (Drager and Olsen, 1981) (see Materials and Methods). Two percent is comparable to that seen in untreated retinas (Nirenberg, unpublished observations) and may thus be a result of trauma associated with dissection and handling of the retina, rather than peripheral damage from the ablation technique. In addition, the ablation was rapid: in 7 of 8 retinas, the targeted cells were labeled with ethidium within $4 \mathrm{hr}$. The ablation treatment was also effective for ablating $\beta$-gal ${ }^{+}$cells in the retinas of newborn mice in vivo: $96 \pm 3 \%$ of AEC-labeled cells were labeled with ethidium within $4 \mathrm{hr}$ of treatment (total number of AEC-labeled cells $=86, n=3$ animals). Finally, in four retinas, the ethidium results were verified using trypan blue.

Further evidence that the targeted cells were ablated was obtained by examining retinas for the loss of $\beta$-gal ${ }^{+}$cells $1-2$ weeks after ablation treatment. Retinas from 25 adult mice, 20 from the VIP- $\beta$-gal transgenic line and five from the rhodopsin- $\beta$ gal line, were injected with FDG/AEC solution and illuminated in vivo. One to two weeks later, the retinas were removed, fixed, and assayed for $\beta$-gal ${ }^{+}$cells, using Xgal, a $\beta$-gal substrate that generates a stable blue precipitate. Twenty-three of twenty-five retinas had large regions that were virtually devoid of $\mathrm{Xgal}^{+}$ cells (Figs. 3, 4). These regions ranged from $10 \%$ to $40 \%$ of the retina, comparable to the sizes of the illuminated areas. The size of each $\mathrm{Xgal}^{-}$region was measured by placing an array of $100 \mu \mathrm{m} \times 100 \mu \mathrm{m}$ sampling grids over a camera lucida drawing of each retina and counting the number of contiguous grids that

Figure 5. Ablation of $\beta$-gal-expressing cells was selective: two cell types that neighbor $\beta$-gal-expressing cells were spared. $A$ and $B$, Border between the ablated and nonablated region of a retina that had been stained with both Xgal (to mark $\beta$-gal ${ }^{+}$cells) and SMI32 (to label a subclass of ganglion cells). $A$, Xgal staining in the border region between the ablated and nonablated areas before SMI32 staining; $B$, The SMI32-stained cells in the identical region. Since Xgal staining is difficult to see in this photograph with SMI32+ staining, blood vessels provide convenient landmarks. $C$ and $D$, The border between the ablated and nonablated region of a retina that had been stained with both Xgal and an antibody to TH (to mark $\mathrm{TH}^{+}$amacrine cells). $C$, Xgal staining in the border region between the ablated and nonablated areas before $\mathrm{TH}$ staining; $D, \mathrm{TH}^{+}$cells in the same region. Because the $\mathrm{TH}^{+}$cells lie below the $\mathrm{Xgal}{ }^{\prime}$ cells, $\mathrm{Xgal}{ }^{\prime}$ cells are not visible in the plane of focus in $D$; arrow in $C$ marks blood vessel used as landmark. $A$ and $C$ were contrast enhanced to show Xgal staining using an image processor. Scale bar: $18 \mu \mathrm{m}$ for $A$ and $B ; 45 \mu \mathrm{m}$ for $C$ and $D$. 


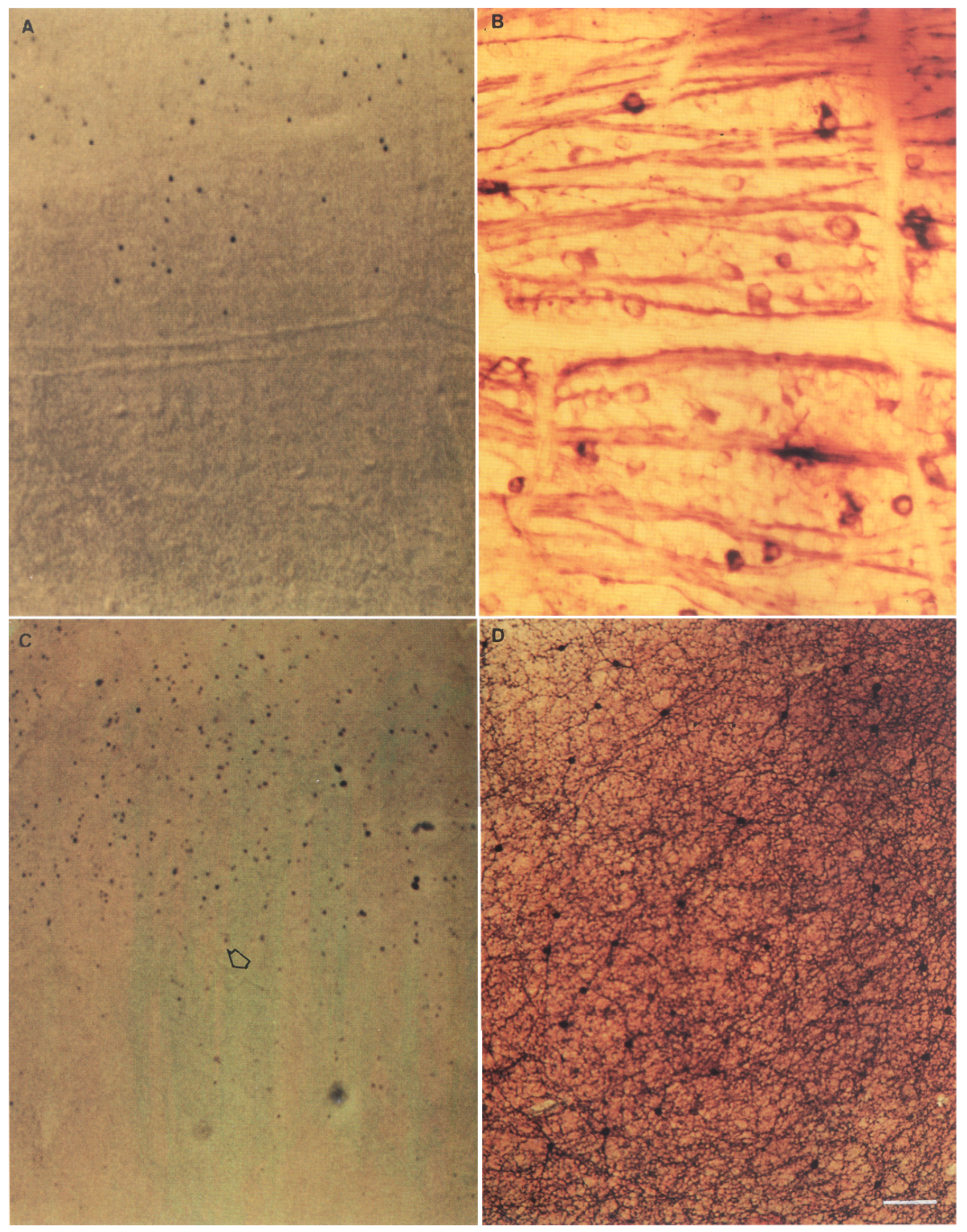


contained two or fewer $\mathrm{Xgal}+$ cells; in fact, the vast majority of sampling grids contained zero cells. The mean density of $\mathrm{Xgal}^{+}$ cells in the ablated regions for all tissues examined was $<3 \%$ of the mean density of $\mathrm{Xgal}^{+}$cells in control retinas. Control retinas were either treated with FDG/AEC and not illuminated $(n=25)$, illuminated but not FDG/AEC treated $(n=10)$, or FDG treated and illuminated but without AEC $(n=5)$ : none contained $\mathrm{Xgal}^{-}$regions. The fact that none of the 40 control retinas showed $\mathrm{Xgal}^{-}$regions argues against the possibility that the $\mathrm{Xgal}^{-}$areas in the treated retinas were due to inadequate or variable expression of the transgene.

Transverse sections through these Xgal-stained, VIP- $\beta$-gal retinas showed no gross morphological differences between the ablated $\left(\mathrm{Xgal}^{-}\right)$and nonablated $\left(\mathrm{Xgal}^{+}\right)$areas (Fig. $\left.3 E, F\right)$. All cell layers were present, including the photoreceptor layer. [The VIP- $\beta$-gal cells constitute a small fraction of cells in the ganglion cell layer $(<10 \%)$ and should not affect layer thickness.] Similarly, in retinas where the rods were selectively targeted, using the rhodopsin- $\beta$-gal transgenic line, sections through the targeted area showed the rods to be obliterated while all other cell layers appeared intact.

To examine further the selectivity of the technique, seven retinas from which the VIP- $\beta$-gal cells had been ablated were examined for the loss of other cell types. One week after ablation, retinas were removed from the animal and stained with $\mathrm{Xgal}$ to mark the $\beta$-gal ${ }^{+}$amacrine cells. The retinas were then stained with one of two antibodies, each of which labels a class of cells that neighbors the VIP- $\beta$-gal cells. SMI32, a monoclonal antibody against the nonphosphorylated epitope of the heavy-molecular-weight neurofilament, labels large-bodied retinal ganglion cells (Nixon et al., 1989). These cells' somata reside in the same layer as the VIP- $\beta$-gal cells and often appear, by light microscopy, to be directly adjacent to VIP- $\beta$-gal cells in doublelabeled retinas. The second antibody, which was generated against the enzyme TH, labels a subclass of amacrine cells in the cell layer below the VIP- $\beta$-gal cells (Wulle and Schnitzer, 1989). All three cell types, the VIP- $\beta$-gal displaced amacrine cells, the $\mathrm{TH}^{+}$ amacrine cells, and the SMI32+ ganglion cells, extend wide, overlapping processes into the plexus layer between the amacrine and ganglion cell/displaced amacrine layers (Wulle and Schnitzer, 1989; Nirenberg, unpublished observations). For each retina, the $\beta$-gal ${ }^{+}$cells and the antibody ${ }^{+}$cells were counted in camera lucida drawings. The number of antibody ${ }^{+}$cells in the ablated $\left(\mathrm{Xgal}^{-}\right)$area of each retina was then compared to the number of antibody ${ }^{+}$cells in an adjacent nonablated ( $\mathrm{Xgal}^{+}$) area. Each comparison was made between two regions equidistant from the optic nerve head to accommodate the gradient in cell density that occurs with retinal eccentricity (Drager and Olsen, 1981; Wulle and Schnitzer, 1989; see Materials and Methods). The densities of both the SMI32+ cells and the $\mathrm{TH}^{+}$ cells in the $\mathrm{Xgal}^{-}$regions were comparable to the densities of these cell types in the $\mathrm{Xgal}^{+}$areas (Figs. 5, 6) and in agreement with densities described for these cell types in previous studies (Hofbauer and Drager, 1985; Wulle and Schnitzer, 1989). Thus, in treated regions of the retina where $\beta$-gal ${ }^{+}$cells had clearly been eliminated, both ganglion cells and TH-amacrine cells remained present in normal numbers and distribution.

\section{Ablation in cerebral cortex}

To test the effectiveness of this technique in other regions of the nervous system, particularly areas less transparent than the retina, the treatment was applied to VIP- and somatostatin- $\beta$ gal neurons in the mouse cortex. For these experiments, the mouse was anesthetized and the cortical surface exposed by opening the skull and reflecting the bone. The FDG/AEC solution was delivered through small holes made in the dura mater or by removing the dura and applying the solution directly to the pial surface. The cortex was then illuminated, using a standard fluorescence microscope, as shown in Figures $1 C$ and $7 B$. After treatment, the brain was removed, sectioned, and examined for the presence of cells containing the photoconverted AEC product (Fig. 7 C). In all 30 animals tested, the AEC precipitate was formed selectively in the fluorescein-labeled cells. In addition, the ablation treatment was applied to somatostatin$\beta$-gal cells in vivo in the cortices of four newborn mice and the animals were then returned to their cages. Three days later, the brains were removed and examined for the loss of $\beta$-gal ${ }^{+}$cells in the targeted area. In all four animals, the targeted (illuminated) area was devoid of $\mathrm{Xgal}^{+}$cells, while surrounding areas showed dense Xgal labeling (Fig. 7D). None of the four shamoperated animals showed $\mathrm{Xgal}^{-}$areas in the operated regions. Three were FDG/AEC treated but not illuminated; one was treated with AEC alone and illuminated. In newborns, somatostatin- $\beta$-gal cells lie in a band approximately $150-300 \mu \mathrm{m}$ below the pial surface. Cells in the deepest layer of this band were ablated, demonstrating that cells at least $300 \mu \mathrm{m}$ deep, approximately half the cortical plate, can be reached.

\section{Ablation in zebrafish embryos}

The cell-killing technique is also potentially applicable to other organisms in which gene transfer can be effected, such as zebrafish, fruit flies, and nematodes. Because these organisms are transparent throughout most or all of their development, cells can be ablated during early organogenesis as well as later in development. We tested the method on zebrafish embryos. Since few promoters have yet been cloned from zebrafish, a viral promoter (the cytomegalovirus immediate-early promoter) and the murine hsp were used to express $\beta$-gal (Kothary et al., 1989; Morgenstern and Land, 1990). These gene constructs, when injected into fertilized eggs, generate mosaic patterns of $\beta$-gal expression in the developing embryo, ranging from small patches (5-20 cells in the embryo) to apparent constitutive expression (Fulwiler et al., unpublished observations). The ablation treatment was applied by immersing the live embryos in Ringer's containing FDG and AEC, immobilizing the embryo and illuminating the tissue of interest (Fig. 8). Selectivity of ablation was examined using seven embryos that showed only a small number of $\beta$-gal ${ }^{+}$cells. Figure $8 E-G$ shows an embryo at the 5 -somite stage with only a few fluorescein-labeled cells. The cells were illuminated using a large spot of light that included the caudal half of the developing fish. The embryo was then examined for propidium exclusion, to assay cell death (Macklis and Madison, 1990). Within 10 min of illumination, the targeted cells were labeled with propidium; no other cells showed the AEC product or propidium label, even though the entire caudal region of the embryo was exposed to light. Of a total of 32 targeted cells in seven embryos, 32 contained the brown precipitate after illumination and 30 of these were subsequently labeled with propidium. There appeared to be virtually no nonspecific killing, as no embryo contained more than four propidium-labeled cells that were not among the fluorescein-labeled population. To test for long-term effects of this treatment on developing embryos, 11 fish not expressing $\beta$-gal were treated in the same manner, including whole-body illumination. The fish were evaluated for $3 \mathrm{~d}$, and all 11 appeared to develop normally. 
A

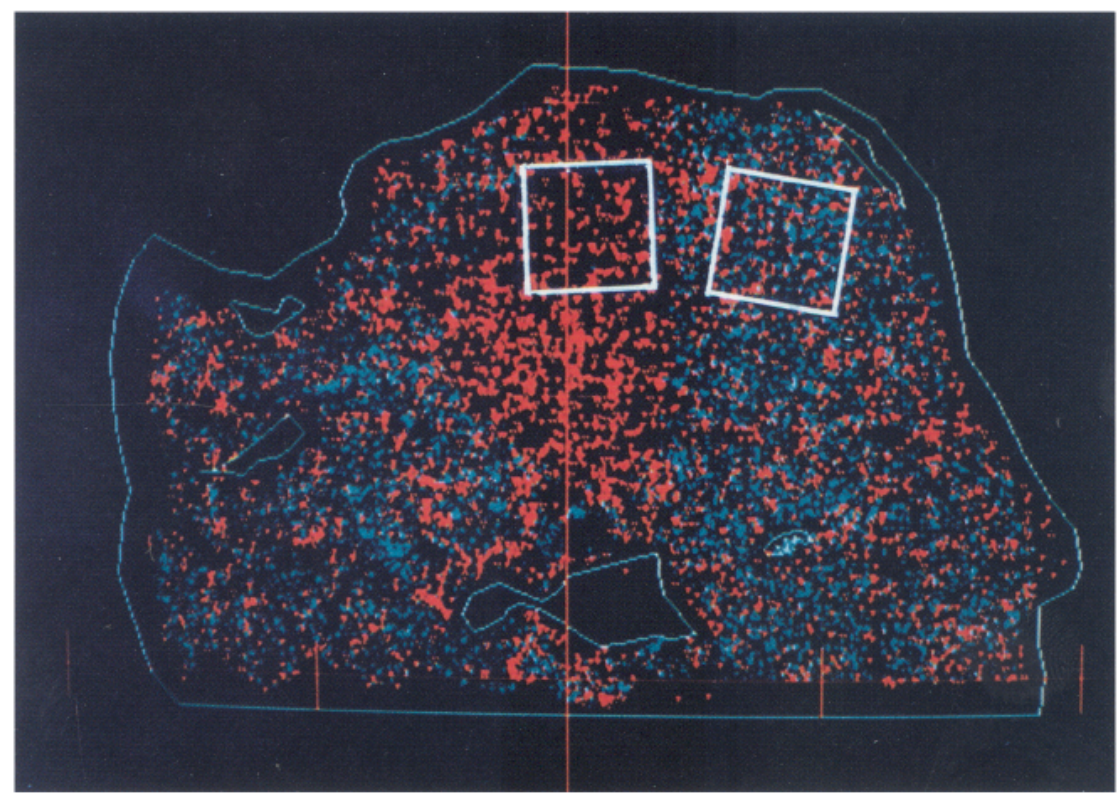

B

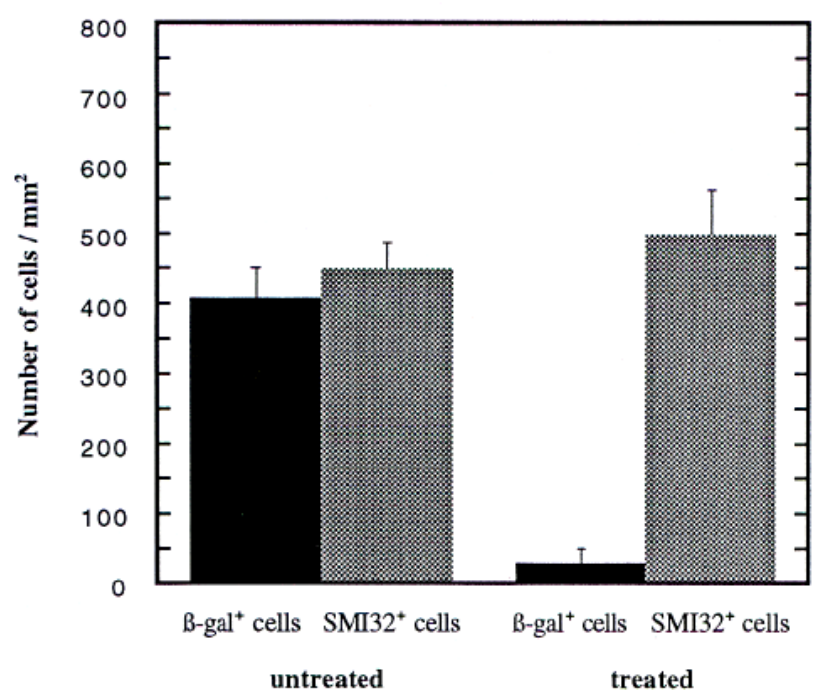

C

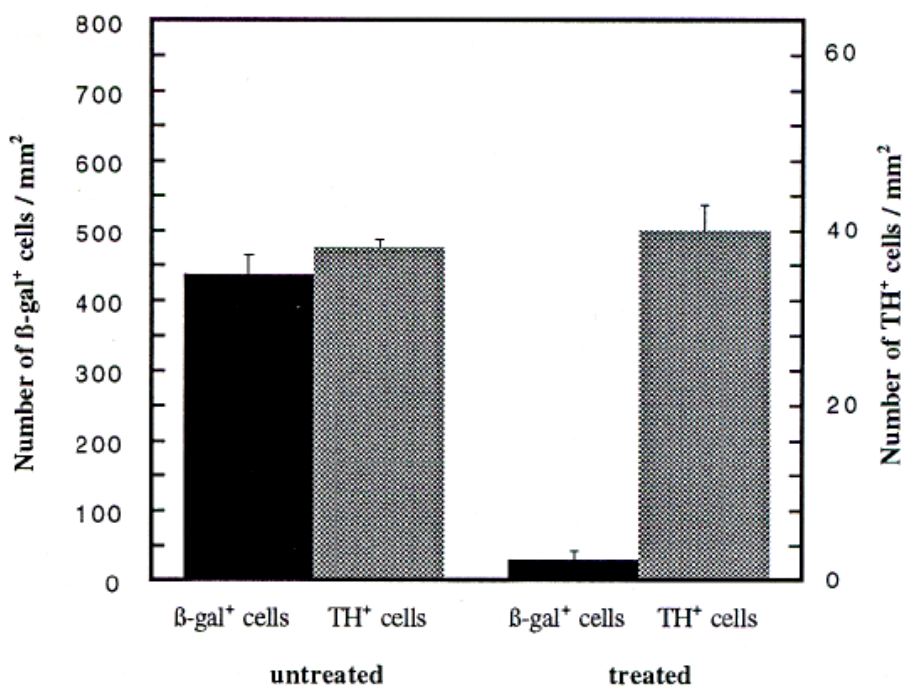

Figure 6. Densities of ganglion cells and $\mathrm{TH}^{+}$amacrine cells in treated and untreated regions of retina. $A$, Camera lucida drawing of inferior half of a retina stained with Xgal (to mark $\beta$-gal ${ }^{+}$cells) and SMI32 (to mark a subclass of ganglion cells) 1 week after ablation treatment had been applied in vivo. Small blue dots represent $\beta$-gal ${ }^{+}$cell bodies; large red triangles represent SMI32+ ${ }^{+}$ganglion cell bodies. The ablated region $\left(\beta\right.$-gal $\left.{ }^{-}\right)$ is located near the center of the drawing. Seven retinas were similarly analyzed: three were stained with Xgal and SMI32, four were stained with Xgal and a TH-specific antibody which labels a subclass of amacrine cells. For each retina, cell density in the ablated region was compared to cell density in an adjacent, nonablated region. Cells were counted from sampling grids $(400 \mu \mathrm{m} \times 400 \mu \mathrm{m}$ for SMI32-stained retinas; $400 \mu \mathrm{m} \times 800$ $\mu \mathrm{m}$ for TH-stained retinas) taken from approximately the same region of each retina for each group. The grids in the ablated and nonablated areas were placed equidistant from the optic nerve head (Drager and Olsen, 1981) (see Material and Methods). B, Mean cell density for the SMI32+ ganglion cells (large-bodied ganglion cells) was $448 \pm 38$ cells $/ \mathrm{mm}^{2}(n=3)$ in the nonablated area and $498 \pm 65 \mathrm{cells} / \mathrm{mm}^{2}$ in the ablated area. These densities are in reasonable agreement with previous reports for this cell type (Drager and Olsen, 1981; Hofbauer and Drager, 1985). $C$, Mean cell density for $\mathrm{TH}^{+}$amacrine cells was $38 \pm 1$ cells $/ \mathrm{mm}^{2}(n=4)$ in the nonablated area and $40 \pm 3$ cells/mm in the ablated area. These densities are also in reasonable agreement with previous findings (Wulle and Schnitzer, 1989). Vertical axis on left in $C$ refers to $\beta$-gal ${ }^{+}$cell number; vertical axis on right refers to $\mathrm{TH}^{+}$cell number.

\section{Discussion}

This article describes a novel method for ablating classes of cells. The targeted cell class is first engineered to express the gene for the enzyme $\beta$-gal. The $\beta$-gal ${ }^{+}$cells are then selectively labeled with a photoactivatable dye (fluorescein) by applying a $\beta$-gal substrate that releases fluorescein when enzymatically cleaved. The fluorescein-labeled cells are then photoablated with the aid of a sensitizing agent, AEC.

The advantage to this approach is that the specificity of the 
Figure 7. In vivo ablation of somatostatin- $\beta$-gal neurons in cerebral cortex. $A$, Schematized view of newborn mouse indicating targeted region of cerebral cortex. $B$, Somatostatin- $\beta$-gal neurons in somatosensory cortex treated with FDG/AEC, viewed from the dorsal surface within the region (box) shown in $A$. FDG/AEC was applied to the pial surface after reflecting the skull above this region of the cortex. The fluorescein-labeled cells were located in a band 150-300 $\mu \mathrm{m}$ below the pial surface. $C$, Transverse coronal section through same cortex, which had been fixed immediately after illumination. AEC oxidation product accumulated in cells labeled with fluorescein. $D$, Camera lucida drawing of a coronal section through a cortex $3 \mathrm{~d}$ after ablation treatment had been applied in vivo. The cortex was examined for the loss of somatostatin$\beta$-gal cells, using Xgal to detect $\beta$-gal activity. Right panel shows normal pattern of somatostatin- $\beta$-gal cells in the right dorsomedial cortex; left panel shows pattern on the treated side. Scale bars: $B, 50 \mu \mathrm{m} ; C, 25 \mu \mathrm{m}$.
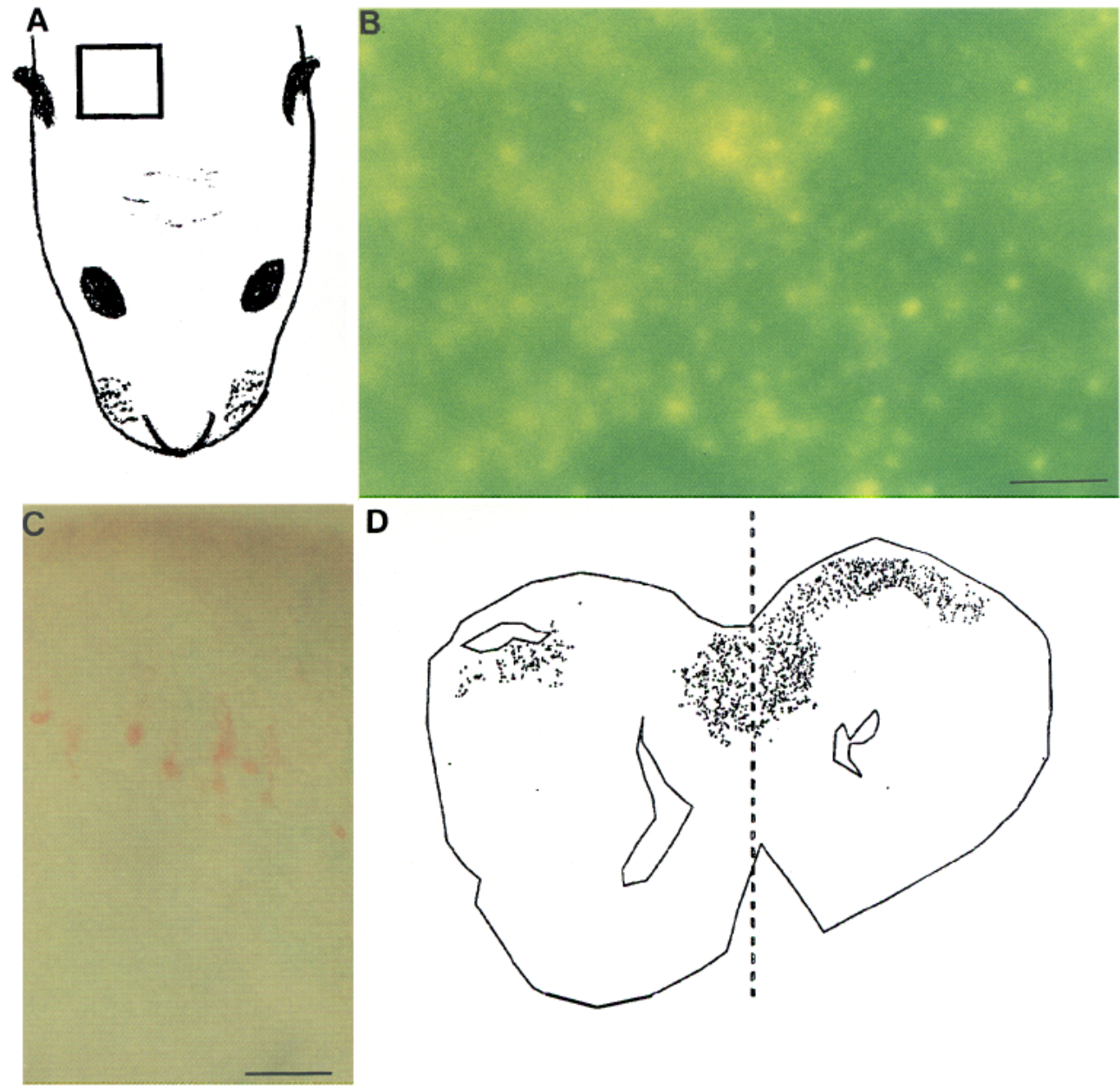

ablation is conferred in two parts-selective gene expression and selective illumination. Ablation occurs only where the two parts are coincident-in cells that both express the gene and receive illumination; thus, a high degree of specificity is achieved without requiring either part, by itself, to be completely specific. This allows a single cell class to be targeted using a promoter that is active in multiple tissues. Restricting the illumination exclusively to the tissue containing the targeted cell class renders the ablation specific. Since completely specific promoters are not required, the repertoire of promoters that can be used to target cells is large, and thus the likelihood of finding a promoter that can be used to target any cell type in the nervous system is very high. For example, we were interested in ablating amacrine cells in the retina, but promoters specific for amacrine cells have not been identified. (It is possible, and perhaps likely, that no promoter specific for amacrine cells even exists, as the unique identity of amacrine cells may be a function of a unique combination of more widely expressed genes.) To target amacrine cells, we used promoters to two neuropeptide genes, VIP and somatostatin. While both genes are expressed in many tissues, they are specific to amacrine cells within the confines of the retina. By illuminating only the retina, the ablation was restricted to amacrine cells. A second advantage to this method is that the time of ablation is flexible. Cells can be ablated at different developmental stages or in the adult. This is particularly important for studying mature neural circuit function, where it is essential to allow the circuit to develop completely before inducing perturbations. Lastly, a technical feature of this technique is that it utilizes a widely used reporter gene, lac Z. A large number of transgenic animals, particularly mice and fruit flies, have already been generated with specific patterns of $\beta$-gal expression.

The effectiveness of this ablation method was tested in vivo and in vitro on three different cell classes in the mouse retina, two cell classes in the cortex, and cells in zebrafish embryos. Two independent assays were used to determine ablation. First, the targeted $\beta$-gal-expressing cells were scored for uptake of ethidium homodimer and trypan blue. Greater than $90 \%$ of the $\beta$-gal ${ }^{+}$cells (identified by the presence of fluorescein or AEC precipitate) were found to label with ethidium or trypan blue.

The second assay was to examine tissue 1-2 weeks after the cell-killing treatment had been applied to see if the targeted $\beta$-gal ${ }^{+}$population was lost from the tissue. Nearly all treated retinas showed large areas, ranging from $10 \%$ to $40 \%$ of the retina, that were devoid of $\beta$-gal ${ }^{+}$cells, while none of the control retinas showed $\beta$-gal ${ }^{-}$areas. The fact that Xgal staining was absent from retinas after a period as long as 1-2 weeks after ablation treatment argues against the possibility that the treatment merely damaged the $\beta$-gal enzyme, rather than the cell in general. Had only enzyme been affected, loss of $\beta$-gal expression would have been transient. The persistent loss of $\beta$-gal activity supports the argument that the $\beta$-gal ${ }^{+}$cells were fundamentally 
-
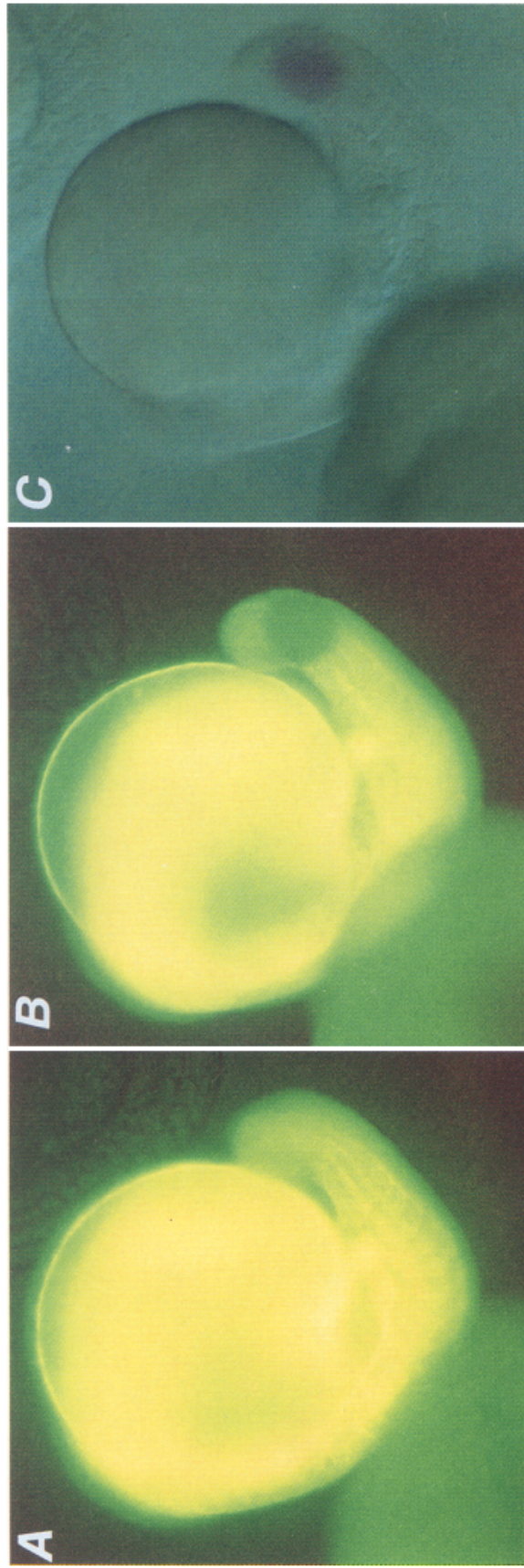

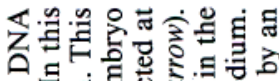
$\pi$ 更

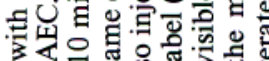
उ《응

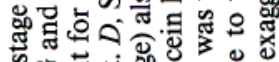

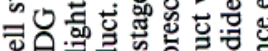
눈 क 을

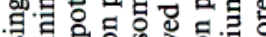

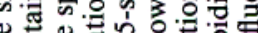

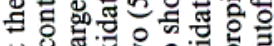

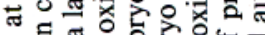

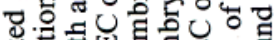

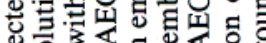

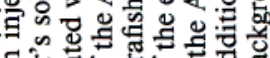

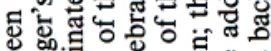
․․ㄹ \&

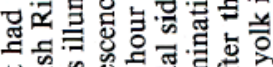

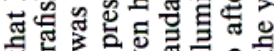

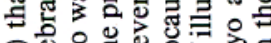

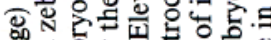

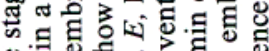
ษ कें

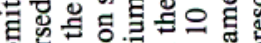

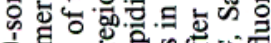

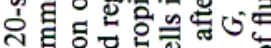
$>$ 웡

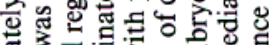

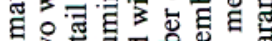

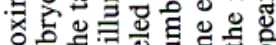

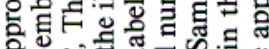

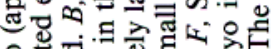

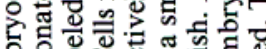

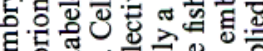

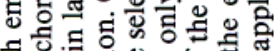

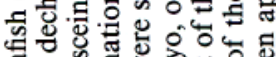

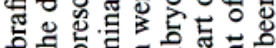

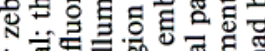
5 和

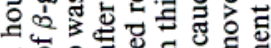

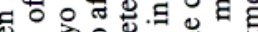

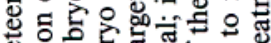

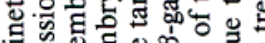
乙

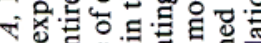

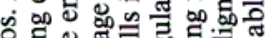
등

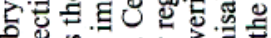

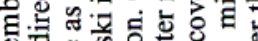

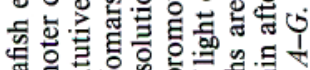

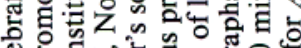

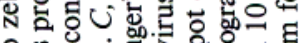
월 में क्षे की

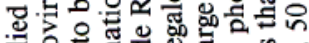

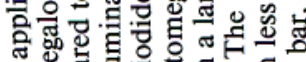

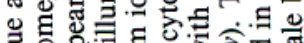

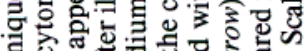

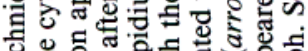

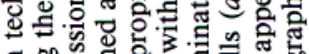

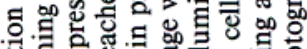

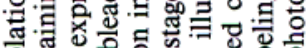

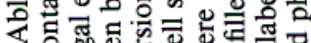

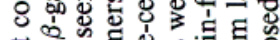

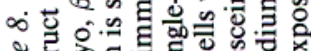
今

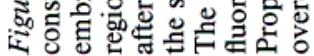


damaged. Moreover, in retinas in which the rhodopsin- $\beta$-gal cells (the rod photoreceptors) were targeted, it was clear that the cells were eliminated, as the photoreceptor layer in the treated areas was largely obliterated. The clear elimination of the rods and the combined results of the ethidium, trypan blue, and Xgal assays, each of which provides independent evidence that the targeted cells were ablated, support the contention that this method is effective in ablating cells.

The selectivity of this ablation technique was examined in two ways. First, the ethidium homodimer and trypan blue assays used to test for ablation also simultaneously tested ablation selectivity. Fewer than $2 \%$ of non- $\beta$-gal ${ }^{+}$cells in the treated region of each retina showed the presence of ethidium or trypan blue. Ablation in zebrafish embryos was also extremely selective: even when whole embryos were subjected to the treatment, ethidium uptake was specific to the $\beta$-gal ${ }^{+}$cells. The second assay for selectivity was to examine retinas for nonspecific cell loss. Retinas from which the VIP- $\beta$-gal cells had been ablated 1-2 weeks earlier were tested for the presence of two cell types, both of which neighbor the targeted population, the SMI32+ ganglion cells and the $\mathrm{TH}^{+}$amacrine cells. Both cell types were present in approximately equal densities in ablated and nonablated areas. Transverse sections through the $\beta$-gal ${ }^{-}$areas provided further evidence that the ablation treatment does not damage tissue nonspecifically. In the VIP- $\beta$-gal retinas, all layers appeared intact including the photoreceptor layer, which contains cells particularly sensitive to illumination.

$\Lambda$ potential problem with this method is that fluorescein can traverse membranes. The concentration of fluorescein in tissue surrounding $\beta$-gal ${ }^{+}$cells was extremely low compared to the concentration inside $\beta$-gal ${ }^{+}$cells (Figs. 1, 2). However, it was possible that fluorescein leakage from $\beta$-gal ${ }^{+}$cells might have caused neighboring cells to be damaged upon illumination. The results from the selectivity assays provided strong evidence that this was not the case. First, if cells surrounding $\beta$-gal ${ }^{+}$cells were being ablated, the ethidium and trypan blue labeling should have appeared in small clusters of cells. Very few of the ethidiumor trypan blue-labeled cells were found to be in clusters, and the frequency of clustering was approximately equal to the normal frequency of clustering for the cell type (Figs. 1, 2). Second, the fact that two neighboring cell types remained intact after the VIP- $\beta$-gal cells were ablated argues that nonspecific damage was minimal. We cannot rule out that neural processes bordering $\beta$-gal + cells were not damaged, although the extensive elaboration of the processes of the TH-labeled cells indicates that damage to nearby processes was low (Fig. $5 D$ ).

Although nonspecific ablation due to fluorescein leakage was not a problem in the several cases shown here, it is a potential problem for other cell types. Nonspecific labeling due to fluorescein leakage is a function of several factors, including promoter strength and cell density; thus, the extent of leak will vary with different $\beta$-gal ${ }^{+}$cell populations. The effects of leakage can be minimized or avoided by illuminating the cells shortly after the application of FDG, before appreciable leak occurs. The leakage of fluorescein after illumination poses no threat as fluorescein itself is nontoxic. In the future, dye leakage may be avoided entirely by using membrane-impermeant fluorescein derivatives coupled to galactose. Two such derivatives, $\mathrm{C}_{12} \mathrm{FDG}$ and $\mathrm{C}_{8} \mathrm{FDG}$, have recently been developed (Zhang et al., 1991).

One limitation of this technique is that the peak excitation wavelength of fluorescein is absorbed by endogenous tissue chromophores, such as Havins and hemoglobin, and does not penetrate deeply into tissue (Anderson and Parrish, 1983; Macklis and Madison, 1990; Batey and Eckhert, 1991). For the adult mouse nervous systems, this method is useful primarily for the upper layers of cortex, the retina, and other light-accessible tissues. In newborn mice, cells throughout the upper half of the cortical plate were readily ablated (Fig. 7). Deeper structures may be reached by inserting fine fiber optics into the ventricles or by utilizing tissue slices in vitro. Light accessibility is not limiting for embryos of other organisms. In the transparent zebrafish embryos, for example, fluorescently labeled cells were. easily visualized in deep structures, such as the heart and the CNS.

In summary, this article describes a new cell ablation technique that should be applicable to a wide variety of cell types. The range of this technique was demonstrated by ablating several different cell types in the mouse retina and cerebral cortex and in zebrafish embryos, using a total of five different promoters. Strong $\beta$-gal enzyme activity does not appear to be required as the VIP- $\beta$-gal and somatostatin- $\beta$-gal cells in the retina showed weak $\beta$-gal activity as determined by Xgal staining, yet were readily ablated (see Fig. 3 ). The temporal flexibility of the method was demonstrated by targeting cells in vivo (both retina and cortex) in newborn mice as well as adults.

Finally, while FDG in conjunction with AEC serves as a means to ablate cells, FDG alone can be used as a live label. Figure 1 demonstrates the labeling of live VIP- $\beta$-gal and somatostatin- $\beta$-gal neurons in the retina and cortex. The ability to identify cells on the basis of gene expression in live tissue is useful for characterizing cells both physiologically and anatomically, particularly as the cells develop.

\section{References}

Anderson RR, Parrish JA (1983) Selective phototherolysis: precise microsurgery by selective absorption of pulsed radiation. Science 220 : 524-527.

Batey DW, Eckhert CD (1991) Analysis of flavins in ocular tissues of the rabbit. Invest Ophthalmol Vis Sci 32:1981-1985.

Beletsky IP, Umansky SR (1990) New assay for cell death. J Immunol Methods 134:201-205.

Bentley D, Caudy M (1983) Pioneer axons lose directed growth after selective killing of guidepost cells. Nature 304:62-65.

Breitman ML, Clapoff S, Rossant J, Tsui LC, Glode LM, Maxwell IH, Bernstein A (1987) Genetic ablation: targeted expression of a toxin gene causes microphthalmia in transgenic mice. Science 238:1563.

Brennan SM (1991) Morphogenetic and molecular correlates of teratogenesis in the amphibian embryo. Teratology 43:341-53.

Cepko CL (1989) Lineage analysis and immortalization of neural cells via retrovirus vectors. In: Neuromethods, Vol 16, Molecular neurobiological techniques (Boulton AA, Baker GB, Campagnoni AT, eds), pp 177-219. Clifton, NJ: Humana.

Cohan CS, Hadley RD, Kater SB (1983) "Zap axotomy" localized fluorescent excitation of single dye-filled neurons induces growth by selective axotomy. Brain Res 270:93-101.

Devanathan S, Dahl TA, Midden WR, Neckers DC (1990) Readily available fluorescein isothiocyanate-conjugated antibodies can be easily converted into targeted phototoxic agents for antibacterial, antiviral, and anticancer therapy. Proc Natl Acad Sci USA 87:2980-2984.

Drager UC, Olsen JF (1981) Ganglion cell distribution in the retina of the mouse. Invest Ophthalmol Vis Sci 20:285-293.

Hofbauer A, Drager UC (1985) Depth segregation of retinal ganglion cells projecting to mouse superior colliculus. J Comp Neurol 234: 465-474.

Kothary R, Clapoff S, Darling S, Perry MD, Moran LA, Rossant J (1989) Inducible expression of an hsp68-lac $Z$ hybrid gene in transgenic mice. Development 105:707-714. 
Krasnow MA, Cumberledge S, Manning G, Herzenberg LA, Nolan GP (1991) Whole animal cell sorting of Drosophila embryos. Science 251:81-85.

Lees GJ (1989) In vivo and in vitro staining of acidophilic neurons as indicative of cell death following kainic acid-induced lesions in rat brain. Acta Neuropathol (Berl) 77:519-524.

Macklis JD, Madison RD (1990) Progressive incorporation of propidium iodide in cultured mouse neurons correlates with declining electrophysiological status: a fluorescence scale of membrane integrity. J Neurosci Methods 31:43-46.

Madison R, Macklis JD, Theis C (1990) Latex nanosphere delivery systcm (LNDS): novel nanomcter-sized carricrs of fluorescent dycs and active agents selectively target neuronal subpopulations via uptake and retrograde transport. Brain Res 522:90-98.

Maranto AR (1982) Neuronal mapping: a photooxidation reaction makes Lucifer yellow useful for electron microscopy. Science 217: 953-955.

Marti E, Gibson SJ, Polak JM, Facer P, Springall DR, Van Aswegen G, Aitchison M, Koltzenburg M (1987) Ontogeny of peptide- and amine-containing neurones in motor, sensory, and autonomic regions of rat and human spinal cord, dorsal root ganglia and rat skin. J Comp Neurol 266:332-359.

Miller JP, Selverston AI (1979) Rapid killing of single neurons by irradiation of intracellularly injected dye. Science 206:702-704.

Morgenstern JP, Land H (1990) A series of mammalian expression vectors and characterization of their expression of a receptor gene in stably and transiently transfected cells. Nucleic Acids Res 18:1068.

Nixon RA, Lewis SE, Dahl D, Marotta CA, Drager U (1989) Early posttranslational modifications of the three neurofilament subunits in mouse retinal ganglion cells: neuronal sites and time course in relation to subunit polymerization and axonal transport. Mol Brain Res 5:93-108.

Nolan GP, Fiering S, Nicolas JF, Herzenberg CA (1988) Fluorescenceactivated cell analysis and sorting of viable mammalian cells based on $\beta$-D-galactosidase activity after transduction of Escherichia coli lacZ. Proc Natl Acad Sci USA 85:2603-2607.

Raper JA, Bastiani MJ, Goodman CS (1984) Pathfinding by neuronal growth cones in grasshopper embryos: the effects of ablating the A and $P$ axons upon the behavior of the $G$ growth cone. $J$ Neurosci 4:2329-2345.

Ruiz MC, Michelangeli F, Ludert JE, Liprandi F, delCastillo JR, Chemello ME, Benaim G, Cohen E (1991) Fluorometric quantification of cell death in monolayer cultures and cell suspensions. J Biochem Biophys Methods 23:237-248.

Schwartz JP, Costa E (1986) Hybridization approaches to the study of neuropeptides. Annu Rev Neurosci 9:277-304.

Steinkamp JA, Habbersett RC, Stewart CC (1987) A modular detector for flow cytometric multicolor fluorescence measurements. Cytometry $8: 353-365$.

Sternberger LA, Sternberger NH (1983) Monoclonal antibodies distinguish phosphorylated and non-phosphorylated forms of neurofilaments in situ. Proc Natl Acad Sci USA 80:6126-6130.

Sulston JE, White JG (1980) Regulation and cell autonomy during post-embryonic development of Caenorhabditis elegans. Dev Biol 78: 577-597.

Tauchi M, Madigan NK, Masland RH (1990) Shapes and distribution of the catecholamine-accumulating neuron in the rabbit retina. J Comp Neurol 293:179-189.

Wiley RG, Stirpe F (1988) Modeccin and volkensin but not abrin are effective suicide transport agents in rat CNS. Brain Res 438:145-154.

Wulle I, Schnitzer J (1989) Distribution and morphology of tyrosine hydroxylase-immunoreactive neurons in the developing mouse retina. Dev Brain Res 48:59-72.

Wayne RP (1988) Principles and applications of photochemistry, $p$ 149. New York: Oxford UP.

Zack DJ, Bennett J, Wang Y, Davenport C, Klaunberg B, Gearhart J, Nathans J (1991) Unusual topography of rhodopsin promoter-lac $Z$ fusion gene expression in transgenic mouse retinas. Neuron 6:187199.

Zackary I, Woll PJ, Rosengurt E (1987) A role for neuropeptides in the control of cell proliferation. Dev Biol 124:295-308.

Zhang YZ, Naleway JJ, Larison KD, Huang Z, Haugland RP (1991) Detecting lacZ gene expression in living cells with new lipophilic, fluorogenic $\beta$-galactosidase substrates. FASEB J 5:3108-3113. 